\section{Cureus}

Received 11/25/2016

Review began 12/06/2016

Review ended 01/12/2017

Published 01/20/2017

\section{(C) Copyright 2017}

Kon Kam King et al. This is an open access article distributed under the terms of the Creative Commons Attribution License CC-BY 3.0., which permits unrestricted use, distribution, and reproduction in any medium, provided the original author and source are credited.

\title{
Comprehensive Review of Non-Operative Management of Hallux Rigidus
}

\author{
Charles Kon Kam King ${ }^{1}$, James Loh SY ${ }^{1}$, Qishi Zheng ${ }^{2}$, Kinjal V. Mehta ${ }^{1}$ \\ 1. Orthopaedics, Changi General Hospital 2. Department of Epidemiology, Singapore Clinical Research \\ Institute
}

$\square$ Corresponding author: Charles Kon Kam King, charles_kon@cgh.com.sg

Disclosures can be found in Additional Information at the end of the article

\section{Abstract}

This article aims to provide an evidence-based literature review for the non-operative management of hallux rigidus. Currently, there is very little article on the evidence for the nonoperative management of hallux rigidus. A comprehensive evidence-based literature review of the PubMed database conducted in November 2016, identified 11 relevant articles out of 560 articles assessing the efficacy of non-operative modalities for hallux rigidus. The 11 studies were then assigned to a level of evidence (I-IV). Individual studies were reviewed to provide a grade of recommendation (A-C, I) according to the Wright classification in support of or against the non-operative modality. Based on the results of this evidence-based review, there is poor evidence (grade $\mathrm{C}$ ) to support use of intra-articular injections for pain relief for a period of three months and fair evidence (grade B) against the use of intra-articular injections for long term efficacy. There is poor evidence (grade $\mathrm{C}$ ) to support manipulation and physical therapy and poor evidence (grade $\mathrm{C}$ ) to support modifications in footwear, insoles and orthotics. There were no good evidence (grade A) recommending any interventions. In general, most of the interventions showed improvement. However, the evidence is poor in recommending orthosis, manipulation and intra-articular injections. There is a need for high-quality Level I randomized controlled trials with validated outcome measures to allow for stronger recommendations to be made. There is no study that looked solely at the use of pharmaceutical oral agents for the treatment of hallux rigidus. Non-operative management should still be offered, prior to surgical management.

Categories: Orthopedics

Keywords: hallux rigidus, osteoarthritis, management, non-operative, intra-articular injection, manipulative therapy, physiotherapy, orthosis

\section{Introduction And Background}

Hallux rigidus was first described in 1887 by Daves-Colley [1]. Hallux rigidus has an estimated incidence of one in 40 in patients aged over 50 years [2]. The first ray is an important weightbearing part of the foot. During the normal stance phase of the gait cycle, the hallux bears twice the load compared with the lesser toes and approximately $40 \%$ to $60 \%$ of the body weight [3]. Forces on the first ray are increased during sporting activity with approximately two to three times the body weight during running and up to eight times body weight in running jumps [4].

Excessive length of the first ray increases the stress concentrated at the metatarsophalangeal (MP) joint during toe-off. People with a long first ray are more prone to developing hallux rigidus [5]. Many other etiologies have been postulated including trauma, abnormally elevated first metatarsal and a positive family history; however, most cases are likely idiopathic [6]. 
The symptoms of hallux rigidus include swelling, joint pain, and stiffness associated with restricted dorsiflexion. At the beginning, the joint swelling is due to synovitis. With the progression of the condition, osteophytes develop around the joint margins, specifically on the dorsal aspect. This further restricts joint motion.

Plain radiographs are used to grade the severity of hallux rigidus. Hattrup and Johnson's classification and Coughlin and Shurnas's classification are the most commonly used ones [7-8]. In grade one of Hattrup and Johnson's classification, there are mild changes with a maintained joint space and minimal spurring. In grade two, there are moderate changes, joint space narrowing, the bony proliferation of the metatarsal head, and phalanx and subchondral sclerosis or cysts. In grade three, there are severe changes with moderate to severe joint space narrowing, extensive bony proliferation, and loose bodies or a dorsal ossicle.

The management of hallux rigidus initially is non-operative. In those that have failed nonoperative treatment, surgical treatment would be offered. Foot orthoses and shoe modification such as limiting the bending of the toe box with the full-length rocker can limit dorsal irritation. In addition, other modalities such as physiotherapy, manipulative therapy, and nonsteroidal anti-inflammatory drugs as well as intra-articular injections form part of our current armamentarium for the non-operative management of hallux rigidus. Surgical management of hallux rigidus would include cheilectomy, arthrodesis, arthroscopy, osteotomy and total, partial or resection arthroplasty.

The aim of this review was to evaluate the different non-operative treatment modalities for hallux rigidus thereby providing a clinical guideline based on the available scientific evidence. There is a little review of the evidence for the non-operative management of hallux rigidus.

\section{Review}

\section{Sources of information and search strategy}

A comprehensive literature review was conducted using the PubMed database. We followed the guidelines proposed by PRISMA declaration (Preferred reporting items for systematic reviews and meta-analyses) [9].

Search interval: up to 1st November 2016.

\section{Selection of studies}

Search criteria in non-operative modality with the following keywords in English: "Hallux rigidus", "non-operative treatment”, "physiotherapy”, “injection”, “orthotic”, "chiropractic therapy” and "conservative management”.

Shortlisted articles were reviewed to identify studies with non-operative treatment and examining their results.

\section{Exclusion criteria were}

Case series with less than five cases were also excluded. Non-English publications were excluded.

\section{Final selection criteria}

For inclusion in this study, each study was then assigned a level of evidence (I-V) in accordance 


\section{Cureus}

with the standards of the Journal of Bone and Joint Surgery [10]. The literature was reviewed by two foot and ankle surgeons and a grade of recommendation (A-C, I) were assigned to each intervention based on the classification of Wright [11]. (Tables 1-2) Studies with recommendation grade $\mathrm{A}, \mathrm{B}$, and $\mathrm{C}$ were reviewed (Figure 1).

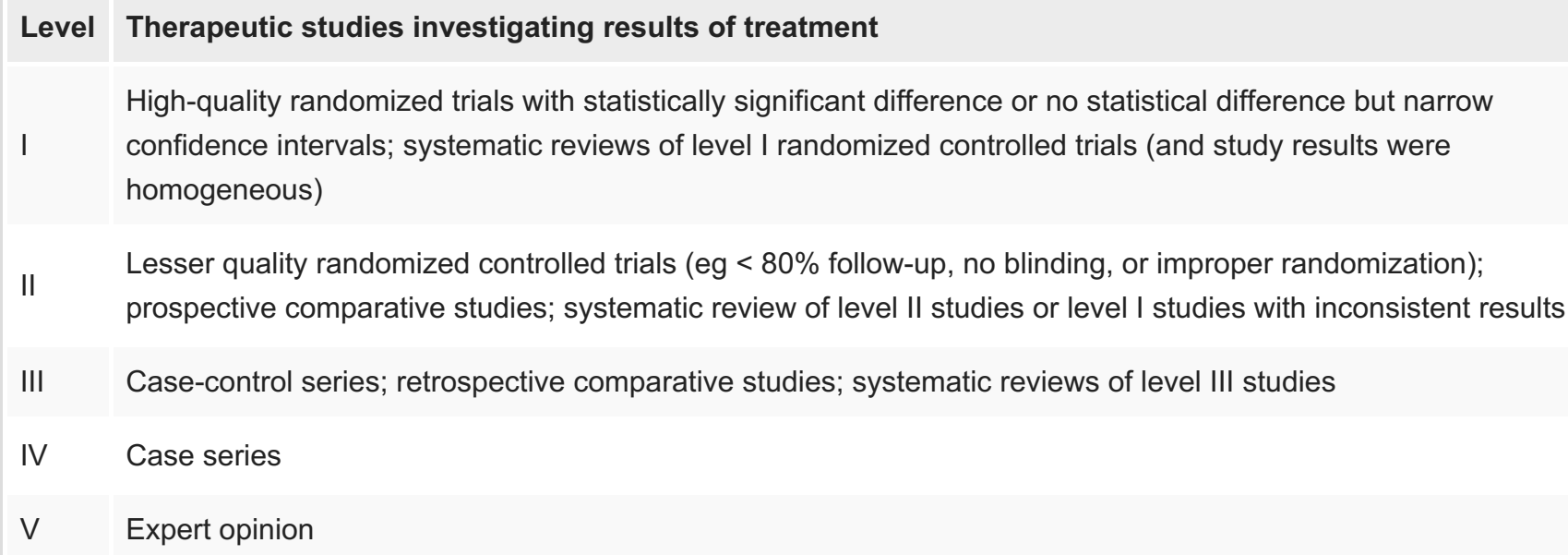

\section{TABLE 1: Levels of evidence for non-operative studies}

\section{Grade Description}

A Good evidence (level-I studies with consistent findings) for or against recommending intervention.

B Fair evidence (level-II or III studies with consistent findings) for or against recommending intervention.

C Conflicting or poor-quality evidence (level-IV or V studies) not allowing a recommendation for or against intervention.

I There is insufficient or conflicting evidence not allowing a recommendation for or against recommending intervention.

\section{TABLE 2: Grades of recommendation for summaries or reviews of orthopaedic} surgical studies 


\section{Cureus}

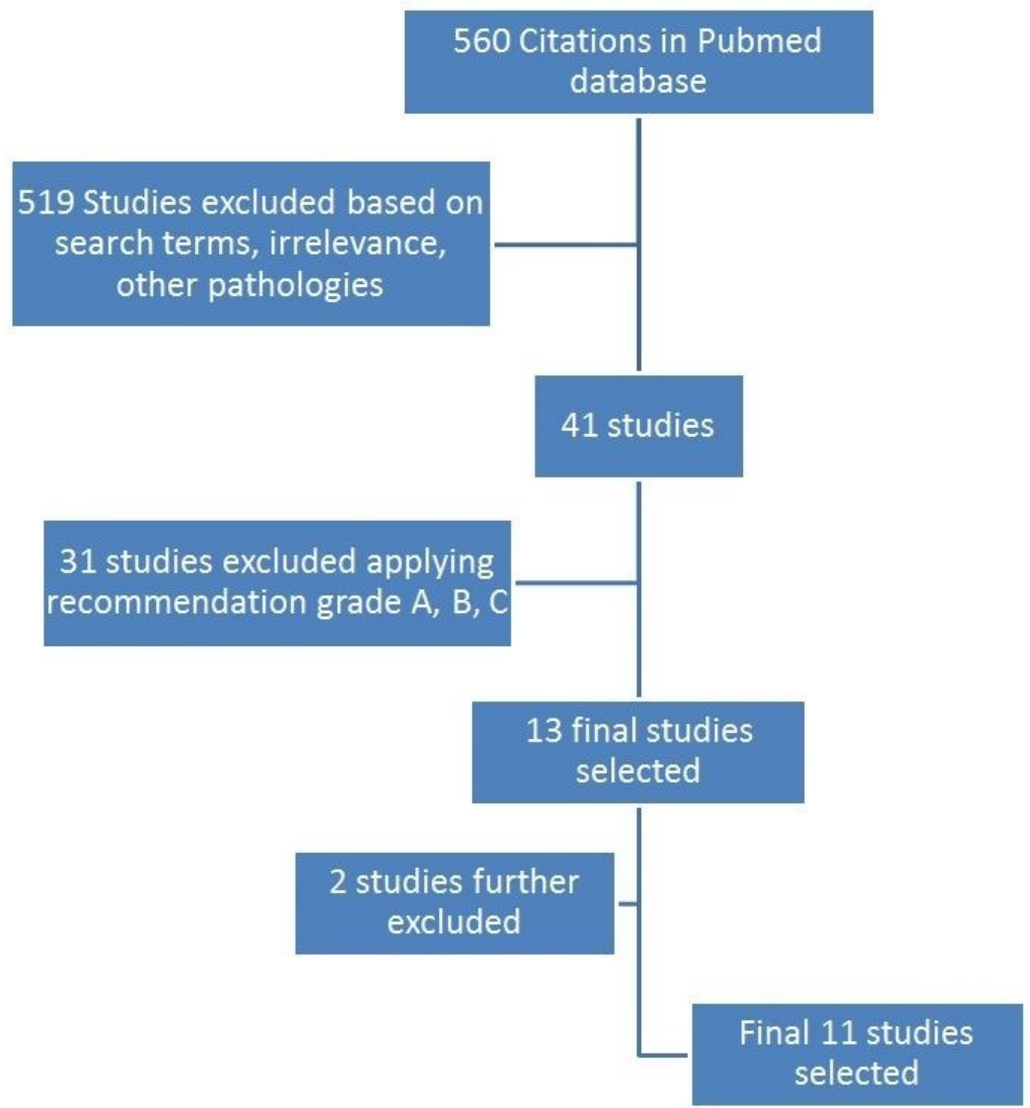

FIGURE 1: PRISMA flow diagram of non-operative modalities

Statistical analysis

A meta-analysis adopting random effect model was performed to synthesize the pre-post changes of VAS for both rest and walking pain, among studies evaluating hyaluronic acid injection [12-13]. Standardized mean difference (SMD) with 95\% confidence interval (95\%CI) was reported. Statistical heterogeneity was assessed by $\mathrm{I}^{2}$ value. For $\mathrm{I}^{2}$ value, $30 \%$ to $50 \%$ represented moderate heterogeneity, $50 \%$ to $80 \%$ substantial heterogeneity and $>80 \%$ considerable heterogeneity [14].

A qualitative synthesis was performed to evaluate various non-surgical interventions reported in the included studies.

The meta-analysis was conducted in Comprehensive Meta-analysis (Version 3.3, Biostat, Englewood, NJ).

\section{Results}

The search returned 560 articles on hallux rigidus. There were 41 articles on non-operative modalities. After applying our exclusion criteria and applying the recommendation grade, there were 13 studies with recommendation grade A, B and C. Two studies were excluded as one study was retracted from the journal and one Cochrane review on this subject matter reviewed, one study that was already included in our shortlist. A total of 11 articles were assessed. There were only three articles that had a recommendation grade B or above. 


\section{Cureus}

The grade of recommendation assigned to each intervention is summarized in Table 3 . Summary of the study characteristics and outcomes are presented in Table 4.

\section{Intervention}

Modifications in footwear, insoles and orthotics

Manipulation and physical therapy

Joint injections (study for intervention)

Joint injections (study against intervention)

\begin{tabular}{|c|c|c|c|c|c|c|}
\hline $\begin{array}{l}\text { Number of } \\
\text { studies }\end{array}$ & $\begin{array}{l}\text { Level } \\
\text { I }\end{array}$ & $\begin{array}{l}\text { Level } \\
\text { II }\end{array}$ & $\begin{array}{l}\text { Level } \\
\text { III }\end{array}$ & $\begin{array}{l}\text { Level } \\
\text { IV }\end{array}$ & Grade & Recommendation \\
\hline
\end{tabular}

3

2

6
Poor quality of evidence recommending intervention

Poor quality of evidence recommending intervention

Poor quality of evidence recommending intervention

Fair evidence against intervention

\section{TABLE 3: Summary of grade of recommendation for or against non-operative modality for hallux rigidus}

\begin{tabular}{|c|c|c|c|c|c|c|c|c|c|}
\hline $\begin{array}{l}\text { Study } \\
\text { (Level) }\end{array}$ & Design & Number & $\begin{array}{l}\text { Follow } \\
\text { up }\end{array}$ & $\begin{array}{l}\text { Age } \\
\text { (year, } \\
\text { SD) or } \\
\text { (year, } \\
\text { range) }\end{array}$ & $\begin{array}{l}\text { Gender } \\
\text { (Female) }\end{array}$ & BMI & Intervention & Outcome & $\begin{array}{l}\text { Treatment } \\
\text { modality } \\
\text { (Recommendation) }\end{array}$ \\
\hline $\begin{array}{l}\text { Grady JF, } \\
2002 \text { (IV) } \\
{[15]}\end{array}$ & Case series & 772 & $\begin{array}{l}>1 \\
\text { year }\end{array}$ & $\begin{array}{l}46 \\
(17- \\
78)\end{array}$ & $\begin{array}{l}375 \\
(49 \%)\end{array}$ & NA & $\begin{array}{l}\text { Conservative } \\
\text { treatment } \\
\text { (orthoses, } \\
\text { corticosteroid, } \\
\text { change in } \\
\text { shoe) }\end{array}$ & $\begin{array}{l}428(55 \%) \text { responded, within which: } \\
362(84 \%) \text { treated successfully with } \\
\text { orthoses } 42(10 \%) \text { with a change in } \\
\text { shoes } 24(6 \%) \text { with steroid injections. } \\
296(38 \%) \text { required surgery } 48(6 \%) \text { did } \\
\text { not respond to conservative or surgery }\end{array}$ & $\begin{array}{l}\text { Modifications in } \\
\text { footwear, insoles } \\
\text { and orthotics } \\
\text { (Treatment provided } \\
\text { pain relief) }\end{array}$ \\
\hline $\begin{array}{l}\text { Smith } \\
\text { RW, } 2000 \\
\text { (IV) [16] }\end{array}$ & Case Series & 22 & $\begin{array}{l}14.4 \\
\text { years }\end{array}$ & $\begin{array}{l}53 \\
(25- \\
71)\end{array}$ & $9(39 \%)$ & NA & $\begin{array}{l}\text { Self-care } \\
\text { methods } \\
\text { (most used a } \\
\text { shoe with } \\
\text { ample toe } \\
\text { box) }\end{array}$ & $\begin{array}{l}63 \% \text { would support original decision of } \\
\text { non-operative treatment } 16 \text { feet }(67 \%) \\
\text { had a measurable loss of cartilage } \\
\text { space } 92 \% \text { of cases the pain level } \\
\text { remained constant }\end{array}$ & $\begin{array}{l}\text { Modifications in } \\
\text { footwear, insoles } \\
\text { and orthotics } \\
\text { (Treatment provided } \\
\text { did not worsen } \\
\text { condition over time) }\end{array}$ \\
\hline $\begin{array}{l}\text { Welsh } \\
\text { BJ, } 2010 \\
\text { (IV) [17] }\end{array}$ & $\begin{array}{l}\text { Single-arm } \\
\text { trial }\end{array}$ & 35 & $\begin{array}{l}24 \\
\text { weeks }\end{array}$ & $\begin{array}{l}42.2 \\
11.5\end{array}$ & 26 & $\begin{array}{l}24.4 \\
3.8\end{array}$ & Foot orthoses & $\begin{array}{l}\text { Foot function index (0-100): Change } \\
\text { from baseline to } 24 \text { weeks: } 14.5 \mathrm{~mm} \\
(\mathrm{P}<0.001) \text { Kinematic analysis: No } \\
\text { systematic change in } 1 \text { st MTP joint } \\
\text { dorsiflexion or ankle/subtalar complex } \\
\text { pronation }\end{array}$ & $\begin{array}{l}\text { Modifications in } \\
\text { footwear, insoles } \\
\text { and orthotics } \\
\text { (Treatment provided } \\
\text { pain relief } \\
\text { comparable to } \\
\text { adequate analgesic } \\
\text { response to }\end{array}$ \\
\hline
\end{tabular}




\section{Cureus}

\begin{tabular}{|c|c|c|c|c|c|c|c|c|c|}
\hline & & & & & & & & & treatment) \\
\hline $\begin{array}{l}\text { Shamus } \\
\text { J, } 2004 \\
\text { (II) [18] }\end{array}$ & $\begin{array}{l}\text { Non- } \\
\text { randomized } \\
\text { controlled } \\
\text { trial }\end{array}$ & 20 & $\begin{array}{l}4 \\
\text { weeks }\end{array}$ & $\begin{array}{l}32.8 \\
5.85\end{array}$ & $15(75 \%)$ & NA & $\begin{array}{l}\text { Sesamoid } \\
\text { joint } \\
\text { mobilization, } \\
\text { flexor hallucis } \\
\text { strengthening } \\
\text { and gait } \\
\text { training vs } \\
\text { Various }\end{array}$ & $\begin{array}{l}\text { MPJ passive range of motion: Control } \\
14.4^{\circ} \pm 8.0^{\circ} \text { Intervention } 42.7^{\circ} \pm 7.8^{\circ} \\
\text { Flexor hallucis strength difference }(\mathrm{Kg}) \text { : } \\
\text { Control } 0.7 \pm 0.4 \text { Intervention } 3.5 \pm 1.0 \\
\text { Change of VAS for rest pain }(0-10 \mathrm{~cm}) \text { : } \\
\text { Control: } 2.6 \pm 1.1 \text { Intervention: } 6.4 \pm 1.3\end{array}$ & $\begin{array}{l}\text { Manipulation and } \\
\text { physical therapy } \\
\text { (Treatment provided } \\
\text { pain relief) }\end{array}$ \\
\hline $\begin{array}{l}\text { Solan } \\
\text { MC, } 2001 \\
\text { (IV) [19] }\end{array}$ & Case Series & 35 & $\begin{array}{l}>12 \\
\text { months }\end{array}$ & $\begin{array}{l}52.3 \\
11.04\end{array}$ & NA & NA & $\begin{array}{l}\text { Manipulation+ } \\
\text { Bupivacaine }\end{array}$ & $\begin{array}{l}\text { Symptomatic relief: Grade } 1 \text { : median } 6 \\
\text { months, } 1 / 3 \text { will require surgery Grade } \\
\text { 2: median } 3 \text { months, } 2 / 3 \text { will require } \\
\text { surgery Grade } 3 \text { : Little or no } \\
\text { symptomatic relief, surgical treatment } \\
\text { planned within } 3 \text { months }\end{array}$ & $\begin{array}{l}\text { Manipulation and } \\
\text { physical therapy } \\
\text { (Treatment provided } \\
\text { pain relief) }\end{array}$ \\
\hline $\begin{array}{l}\text { Munteanu } \\
\text { SE, } 2011 \\
\text { (II) [21] }\end{array}$ & $\begin{array}{l}\text { Randomized } \\
\text { controlled } \\
\text { trial }\end{array}$ & 151 & $\begin{array}{l}6 \\
\text { months }\end{array}$ & $\begin{array}{l}54.5 \\
11.3\end{array}$ & $56(37 \%)$ & $\begin{array}{l}27.1 \\
3.8\end{array}$ & $\begin{array}{l}\text { Hylan G-F } 20 \\
\text { vs Saline }\end{array}$ & 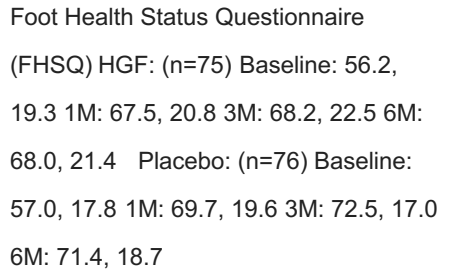 & $\begin{array}{l}\text { Intra-articular } \\
\text { injection (Treatment } \\
\text { did not provide pain } \\
\text { relief. Treatment is } \\
\text { similar to placebo) }\end{array}$ \\
\hline $\begin{array}{l}\text { Pons M, } \\
2007 \text { (I) } \\
{[22]}\end{array}$ & $\begin{array}{l}\text { Randomized } \\
\text { controlled } \\
\text { trial }\end{array}$ & 37 & $\begin{array}{l}12 \\
\text { months }\end{array}$ & $\begin{array}{l}62(40 \\
-80)\end{array}$ & 31 (84\%) & NA & $\begin{array}{l}\text { Sodium } \\
\text { hyaluronate } \\
(\mathrm{SH})(n=20) \\
\text { vs } \\
\text { Triamcinolone } \\
\text { acetonide } \\
(\mathrm{TA})(n=20)\end{array}$ & $\begin{array}{l}\text { VAS for rest pain }(0-100 \mathrm{~mm}) \text { : SH: } \\
\text { Baseline: } 62.2 \pm 10.7 \text { 3M: } 26.2 \pm 23.9 \\
\text { TA: Baseline: } 58.7 \pm 11.63 \mathrm{M}: 34.1 \pm \\
\text { 16.6 VAS for walking pain (0-100mm): } \\
\text { SH: Baseline: } 61.4 \pm 13.0 \text { 3M: } 24.224 .1 \\
\text { TA: Baseline: } 59.3 \pm 12.23 \mathrm{M}: 36.8 \pm \\
\text { 19.7 AOFAS SH: Baseline:51 3M:77.6 } \\
\text { TA Baseline:48.2 3M:64.3 }\end{array}$ & $\begin{array}{l}\text { Intra-articular } \\
\text { injection (Treatment } \\
\text { provided pain relief } \\
\text { at } 3 \text { months, } \\
\text { however at } 1 \text { year } \\
\text { SH } 7 / 15 \text { ( } 46.6 \% \\
\text { required surgery } \\
\text { and TA 9/17 } \\
(52.9 \% \text { ) require } \\
\text { surgery) }\end{array}$ \\
\hline $\begin{array}{l}\text { Grice J, } \\
2016 \text { (IV) } \\
\text { [23] }\end{array}$ & Case Series & 365 & $\begin{array}{l}24 \\
\text { months }\end{array}$ & $\begin{array}{l}41(14 \\
-82)\end{array}$ & NA & NA & $\begin{array}{l}\text { Corticosteroid } \\
\text { injection }\end{array}$ & $\begin{array}{l}\text { Significant improvement }(n=365) \text { Overall } \\
314(86 \%)>3 M: 202(55 \%)>6 M: 145 \\
(39 \%)>2 Y: 107(29 \%) \quad \text { Significant } \\
\text { improvement }(n=22 \text { for hallux rigidus) } \\
\text { Overall } 20(91 \%)>3 M: 3(14 \%)>6 M: 3 \\
(14 \%)>2 Y: 2(9 \%) \text { Required surgery: } \\
88(24 \%)\end{array}$ & $\begin{array}{l}\text { Intra-articular } \\
\text { injection (Treatment } \\
\text { provided did not } \\
\text { offer pain relief for } \\
\text { longer than } 3 \\
\text { months) }\end{array}$ \\
\hline $\begin{array}{l}\text { Maher A, } \\
2007 \text { (IV) } \\
{[24]}\end{array}$ & Case Series & 16 & $\begin{array}{l}12 \\
\text { months }\end{array}$ & NA & NA & NA & $\begin{array}{l}\text { Hyaluronic } \\
\text { acid injection }\end{array}$ & $\begin{array}{l}\text { VAS for rest pain }(0-10 \mathrm{~cm}) \text { : Baseline: } 6.2 \\
\text { (1-9) Post: } 2.8(0-8.5) \quad \text { Sig. } \\
\text { improvement <1M: } 3(23 \%)<6 \mathrm{M}: 3 \\
(23 \%)>6 \mathrm{M}: 6(46 \%)\end{array}$ & $\begin{array}{l}\text { Intra-articular } \\
\text { injection (Treatment } \\
\text { provided pain relief) }\end{array}$ \\
\hline $\begin{array}{l}\text { Petrella } \\
\text { RJ and } \\
\text { Cogliano } \\
\text { A, } 2004 \\
\text { (IV) [25] }\end{array}$ & $\begin{array}{l}\text { Single-arm } \\
\text { trial }\end{array}$ & 47 & $\begin{array}{l}>16 \\
\text { weeks }\end{array}$ & $\begin{array}{l}71, \\
4.3\end{array}$ & $0(0 \%)$ & $\begin{array}{l}26.3 \\
1.7\end{array}$ & $\begin{array}{l}\text { Hyaluronic } \\
\text { acid injection }\end{array}$ & $\begin{array}{l}\text { VAS for rest pain }(0-100 \mathrm{~mm}) \text { : Baseline: } \\
41.2 \pm 3.14 \mathrm{M}: 30.4 \pm 2.9 \text { GPS: } \\
\text { Baseline } 3.14 \mathrm{M}: 4.51 \text { VAS for walking } \\
\text { pain }(0-100 \mathrm{~mm}) \text { : Baseline: } 68.9 \pm 5.9 \text {, } \\
4 \mathrm{M}: 32.8 \pm 3.1\end{array}$ & $\begin{array}{l}\text { Intra-articular } \\
\text { injection (Treatment } \\
\text { provided pain relief) }\end{array}$ \\
\hline
\end{tabular}




\section{Cureus}

\section{TABLE 4: Summary of study characteristics and outcomes}

Abbrevations: VAS, visual analog score; M, months; Y, year; MPJ, metatarsophalangeal joint; GPS, Global Patient Satisfaction scale, AOFAS, American Orthopaedic Foot and Ankle Society score for hallux evaluation

Levels III-IV. The highest quality study examining the outcome of use of orthoses was a level III study (Table 4). Grady, et al. [15] reported that out of 772 patients with symptomatic hallux limitus ( $\mathrm{n}=772), 428$ (55\%) patients were successfully treated conservatively with 362 (84\%) of these 428 patients treated with the use of orthoses (level IV). Two hundred and ninty six (38\%) patients required surgery and 48 (6\%) patients did not respond to conservative management.

Smith, Katchis and Ayson [16] conducted a longitudinal questionnaire-based study of 22 patients with 24 feet $(n=24)$ with an average follow-up of 14.4 years (level IV). Thirteen patients managed with modifications to their shoes by using shoes with ample room in the toe box. Seven patients found that they had relief of their symptoms by avoiding high heels. Of all the patients, $63 \%$ would support their original decision of non-operative treatment. It was also found that pain level remained constant in $92 \%$ of cases over an average of 14.4 years and there was no correlation between subjective complaints and radiographic evidence of progression of hallux rigidus.

Welsh, et al. [17] conducted an observational study with a group treated with foot orthoses $(n=35)$ with a follow-up of 24 weeks (level IV). The pain score as measured on the modified pain subscale of the foot function index (FFI) was $48 \mathrm{~mm}$ at baseline and improved to $14.5 \mathrm{~mm}$ at the end of 24 weeks ( $p$ <001). The authors concluded that orthotic design could offer a reduction in mechanically induced pain to a level that is considered an adequate analgesic response to treatment. The author's study was supported in party through an unrestricted grant from the foot orthoses company.

Grade of recommendation. Based on the previously mentioned literature, the non-operative modality of modifications in footwear, insoles and orthotics is assigned a grade $\mathrm{C}$ recommendation (poor evidence, level IV or V studies with consistent findings) in treatment of hallux rigidus.

\section{Manipulation and physical therapy}

Levels II-IV. There was one level II study and one level IV study looking at manipulation and physical therapy as a treatment modality. Both studies were for the use of manipulation and physical therapy for the treatment of hallux rigidus. Shamus, et al. [18] conducted a prospective randomized study of an intervention group with physical therapy and manipulation $(\mathrm{n}=10)$ and a control group $(n=10)$ over four weeks with a total of 12 therapy sessions (level II). The outcome measured was 1st metatarsophalangeal (MTP) joint range of motion which was $42.7^{\circ} \pm$ $7.8^{\circ}$ in the intervention group compared to $14.4^{\circ} \pm 8.0^{\circ}$ in the control group $(\mathrm{p}<0.001)$. Flexor hallucis strength difference from pretest and post-test of $3.5 \mathrm{Kg} \pm 1.0$ in the intervention group and $0.7 \mathrm{Kg} \pm 0.4$ in the control group ( $\mathrm{p}<0.001$ ). Lastly, the pain level difference based on a 
verbal analog scale of zero to 10 showed a difference of $6.4 \pm 1.3$ in the intervention group compared to $2.6 \pm 1.1$ in the control group ( $\mathrm{p}<0.001)$. The authors concluded that for individuals aged between 26 to 43 years of age, this approach resulted in significant increase in range of motion, strength and function. There was also no adverse outcome reported.

Solan, Calder and Bendall [19] conducted a retrospective case series of 29 consecutive patients with 35 MTP joints ( $\mathrm{n}=35)$ with manipulation under anaesthetic and injection of $40 \mathrm{mg}$ of Depo-medrone made up in $3 \mathrm{ml}$ of $0.5 \%$ bupivacaine with a minimum follow-up of one year (level IV). The authors subdivided the patients according to Karasick and Wapner radiographic classification [20]. They reported that patient with grade one had symptomatic pain relief for a median of six months, although $1 / 3$ will require surgery. Those with grade two had pain relief for a median of three months with $2 / 3$ requiring surgery and finally those with grade three had little to no pain relief with surgical treatment planned within three months.

Grade of recommendation. Based on the previously mentioned literature, the non-operative modality of manipulation and physical therapy is assigned a grade $\mathrm{C}$ recommendation (poor evidence, level IV or V studies with consistent findings) supporting it as an effective treatment for hallux rigidus.

\section{Pharmaceutical therapy with joint injections}

Levels II-IV. There were six studies that looked at intra-articular injections. Munteanu, et al. [21] conducted a randomized placebo controlled study on a group of patients given intraarticular hyaluronan $(n=75)$ and placebo, saline $(n=76)$ over six months (level II). The authors found that the pain score as measured from the foot pain domain of the Foot Health Status Questionniare (FHSQ) was 68.0 at six months for the intervention group and 71.4 at six months for the placebo group ( $\mathrm{p}=0.312$ ). They concluded that single intra-articular injection of hyaluronan was no more effective than placebo. In addition, they did not find any major safety issues with the injections. This study was funded by the Australian Podiatry Education and Research Foundation and La Trobe University Faculty of Health Sciences as well as the provider of the hyaluronan product.

Pons, et al. [22] conducted a single blind randomized study with a group treated with sodium hyaluronate injection $(n=20)$ and another group treated with triamcinolone acetonide $(n=20)$ over 12 months (level I). The authors treated patients who had grade one osteoarthritic change on radiograph according to the Karasick and Wapner classification. The treatment group with sodium hyaluronate had a mean visual analog score from baseline to end of study of $62.2 \mathrm{~mm} \pm$ 10.7 to $26.2 \mathrm{~mm} \pm 23.9$ while the triamcinolone acetonide group had a visual analog score from baseline to end of study $58.7 \mathrm{~mm} \pm 11.6$ to $34.1 \mathrm{~mm} \pm 16.6(\mathrm{p}<0.05)$. They concluded that both intra-articular injections resulted in decrease in pain and improvement of function at three months after injection. However, they found that at one year follow-up, there was a high percentage in both groups that required surgery. There were no major safety issues.

Grice, et al. [23] in their retrospective case series of a group treated with corticosteroid (0.5\% Marcaine with $40 \mathrm{mg}$ Depo-medrone) in the foot and ankle ( $\mathrm{n}=365)$ over a period of two years (level IV). In the subgroup of patients with hallux rigidus $(n=22)$ they found that $91 \%$ had pain relief but that the benefit lasting more than six months was just $14 \%$. They concluded that corticosteroid injections appeared ineffective in providing significant pain relief for more than three months in conditions such as hallux rigidus.

Maher and Price [24] in their retrospective case series with a group treated with intra-articular sodium hyaluronate $(n=16)$ over a period of one year (level IV) found that pain measured on the visual analog scale improved from a mean of $6.2 \mathrm{~cm}$ (range 1-9) pre-injection to $2.8 \mathrm{~cm}$ (range 
0-8.5) post injection. Six out of 14 patients reported pain relief of at least six months since final injection. The authors concluded that intra-articular injection did appear to offer pain relief but did mention that the small number in study subjects. No adverse effect was reported.

Petrella and Cogliano [25] conducted a prospective study with a group, with the treatment with the intra-articular injection of hyaluronic acid $(n=47)$ with a minimum follow of 16 weeks (level IV). They reported pain relief from baseline to follow-up at 16 weeks from $41.2 \mathrm{~mm} \pm 431$ to $30.4 \mathrm{~mm} \pm 2.9$ ( $\mathrm{p}<0.01)$. They concluded that hyaluronic acid did provide pain relief.

Steinberg [26] conducted a retrospective case series of a group treated with intra-articular weekly injections of lidocaine ( $n=100$, level IV). He concluded that 11 patients did not respond to the treatment and went on to have surgery. The period of follow-up and the outcome measures were not reported.

Grade of recommendation. Based on the previously mentioned literature, the non-operative modality of pharmaceutical therapy including joint injections is assigned a grade B recommendation (fair evidence, level II or III studies with consistent findings) against it as an effective treatment for hallux rigidus. There is one study (level II) that show that intra-articular injections are no more effective that placebo and another study (level I) that shows that it is effective at three months, but by one year, nearly half of the patients would require surgery. In addition, there is one study (level IV) that shows that injections are not effective for pain relief after three months. However, there are three studies (level IV) that show that injections do work for treatment of hallux rigidus.

\section{Meta-analysis on hyaluronic acid injection}

Three studies reported VAS of rest pain before and after the injection and three reported VAS of walking pain. Significant reliefs from the injection were observed in both VAS measures, in which pooled VAS of rest pain was -0.52 (95\%CI: $-0.77,-0.28)$ and walking pain was -0.32 (95\%CI: -0.52, -0.11) (Figure 2).

Both I2 of VAS of rest pain and walking pain were zero percent and $10.2 \%$, suggesting that the included studies were in low heterogeneous.

\begin{tabular}{|c|c|c|c|c|c|c|}
\hline \multirow{2}{*}{$\begin{array}{l}\text { Group by } \\
\text { Outcome }\end{array}$} & \multirow[t]{2}{*}{$\underline{\text { Study name }}$} & \multicolumn{3}{|c|}{ Statistics for each study } & \multirow[b]{2}{*}{ Total } & \multirow[b]{2}{*}{$\begin{array}{l}\text { Relative } \\
\text { weight }\end{array}$} \\
\hline & & $\begin{array}{l}\text { Std diff } \\
\text { in means }\end{array}$ & $\begin{array}{c}\text { Lower } \\
\text { limit }\end{array}$ & $\begin{array}{c}\text { Upper } \\
\text { limit }\end{array}$ & & \\
\hline Rest pain & Pons M, 2007 & -0.71 & -1.24 & -0.18 & 17 & 20.63 \\
\hline Rest pain & Maher A, 2007 & -0.81 & -1.41 & -0.20 & 14 & 16.13 \\
\hline Rest pain & Petrella RJ, 2014 & -0.39 & -0.69 & -0.10 & 47 & 63.24 \\
\hline Rest pain & & -0.52 & -0.77 & -0.28 & 78 & \\
\hline Walking pain & Pons M, 2007 & -0.71 & -1.24 & -0.18 & 17 & 35.07 \\
\hline Walking pain & Petrella RJ, 2014 & -0.29 & -0.59 & -0.00 & 47 & 64.93 \\
\hline Walking pain & & -0.44 & -0.83 & -0.05 & 64 & \\
\hline
\end{tabular}

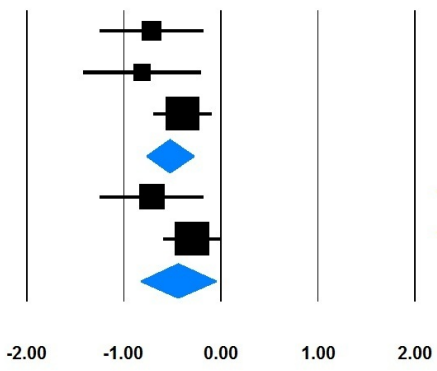

FIGURE 2: Forest plot of VAS for both rest pain and walking pain

\section{Discussion}

We have reviewed the non-operative options for hallux rigidus and evaluated the level of 
evidence based on the most current available literature. Due to the limited studies available, we performed a qualitative summary of the current evidence of non-surgical interventions.

Overall, most of the interventions showed improvement after the intervention. It was shown that a combination of sesamoid joint mobilization, flexor hallucis strengthening and gait training lead to a significant increase in flexor hallucis range of motion, strength and function compared to traditional treatment. The systematic review by Brantingham, et al. [27] reported a grade $\mathrm{C}$ recommendation for manipulative therapy of the ankle and/or foot combined with multimodal or exercise therapy for plantar fasciitis, metatarsalgia, and hallux limitus/rigidus. This further confirms the evidence for this treatment modality.

Hyaluronic acid injection, as synthesized by the meta-analysis, showed a significant improvement on both rest and walking pain level. Six patients (46\%) in Maher A, 2007 studies reported a significant improvement lasting more than six month. Steinberg MD, 1971 reported an $89 \%$ response rate after receiving injection with $2 \mathrm{cc}$ of $2 \%$ lidocaine (Xylocaine) at weekly intervals. However, there are two studies (level I and level II) that showed that injections are not effective on the long term over one year and one study (level IV) that showed that its pain relief was only effective up to three months.

There were no standardized endpoints across included studies, six studies reported visual analogue scale (VAS) and other continuous index for measuring the pain level, two studies reported kinematic analysis on the 1st MTP joint motion, and five studies reported various binary endpoint (Yes/No) on pain relief within a certain period. There was only one nonoperative modality (good evidence, level one study). The majority of evidence available was based on level IV studies. None of the studies looked into the sole use of oral analgesics as a treatment of hallux rigidus.

A potential source of bias is the inclusion of studies with different radiological grades of hallux rigidus. This can lead to a biased inclusion and selection. Additionally, longer follow-up periods and larger study groups would provide better evidence.

\section{Conclusions}

Based on the results of this review, there is fair evidence (grade B) against the use of the nonoperative treatment of intra-articular injections. There is poor evidence (grade C) in support of modifications of footwear, insoles and orthotics and poor evidence (grade C) in support of manipulation and physical therapy.

\section{Additional Information} Disclosures

Conflicts of interest: In compliance with the ICMJE uniform disclosure form, all authors declare the following: Payment/services info: All authors have declared that no financial support was received from any organization for the submitted work. Financial relationships: All authors have declared that they have no financial relationships at present or within the previous three years with any organizations that might have an interest in the submitted work. Other relationships: All authors have declared that there are no other relationships or activities that could appear to have influenced the submitted work.

\section{References}

1. Coughlin MJ, Shurnas PS: Hallux rigidus: demographics, etiology, and radiographic assessment. Foot Ankle Int. 2003, 24(10):731-743. 
2. Hamilton WG, O’Malley MJ, Thompson FM, Kovatis PE: Capsular interposition arthroplasty for severe hallux rigidus. Foot ankle Int. 1997, 18(2):68-70. 10.1177/107110079701800204

3. Rosenfield JS, Trepman E: Treatment of sesamoid disorders with a rocker sole shoe modification. Foot Ankle Int. 2000, 21(11):914-5..

4. Nihal A, Trepman E, Nag D.: First ray disorders in athletes. Sports Med Arthrosc. 2009, 17(3):160-166. 10.1097/JSA.0b013e3181a5cb1f

5. Nilsonne H: Hallux Rigidus and its treatment. Acta Orthop Scand. 1930, 1:295-303. 10.3109/17453673008991145

6. Clanton TO, Ford JJ: Turf toe injury. Clin Sports Med. 1994, 13(4):731-741.

7. Hattrup SJ, Johnson KA: Subjective results of Hallux Rigidus following treatment with cheilectomy. Clin Orthop Relat Res. 1988, 226:182-91.

8. Coughlin MJ, Shurnas PS: Hallux rigidus. Grading and long-term results of operative treatment. J Bone Joint Surg Am. 2003, 85-A(11):2072-2088.

9. Moher D, Liberati A, Tetzlaff J, Altman DG: Preferred reporting items for systematic reviews and meta-analyses: the PRISMA statement. BMJ. 2009, 339:873-880. 10.1136/bmj.b2535

10. Gerald S, Mohit B, MD: Introducing levels of evidence to the journal of orthopedic trauma: implementation and future directions. J Orthop Trauma. 2012, 26:127-128. 10.1097/BOT.0b013e318247c931

11. Wright JG, Einhorn TA, Heckman JD: Grades of recommendation. J Bone Joint Surg Am. 2005, 87(9):1909-1910. 10.2106/JBJS.8709.edit

12. Borenstein M, Hedges L V, Higgins JPT, Rothstein HR: A basic introduction to fixed-effect and random-effects models for meta-analysis. Res Synth Methods. 2010, 1(2):97-111.

10.1002/jrsm.12

13. Nikolakopoulou A, Mavridis D, Salanti G: How to interpret meta-analysis models: fixed effect and random effects meta-analyses. Evid Based Ment Health. 2014, 17(2):64. 10.1136/eb-2014101794

14. Higgins JPT, Green S: Cochrane handbook for systematic reviews of interventions version 5.1.0 [updated March 2011]. The Cochrane Collaboration. 2011. Table 7.7.a:Formulae for combining groups.

15. Grady JF, Axe TM, Zager EJ, Sheldon LA: A retrospective analysis of 772 patients with hallux limitus. J Am Podiatr Med Assoc. 2002, 92(2):102-108. 10.7547/87507315-92-2-102

16. Smith RW, Katchis SD, Ayson LC: Outcomes in hallux rigidus patients treated nonoperatively: a long-term follow-up study. Foot Ankle Int. 2000, 21(11):906-913.

17. Welsh BJ, Redmond AC, Chockalingam N, Keenan AM: A case-series study to explore the efficacy of foot orthoses in treating first metatarsophalangeal joint pain. J Foot Ankle Res. 2010, 3:17. 10.1186/1757-1146-3-17

18. Shamus J, Shamus E, Gugel RN, Brucker BS, Skaruppa C: The effect of sesamoid mobilization, flexor hallucis strengthening, and gait training on reducing pain and restoring function in individuals with hallux limitus: a clinical trial. J Orthop Sports Phys Ther. 2004, 34(7):368376. 10.2519/jospt.2004.34.7.368

19. Solan MC, Calder JD, Bendall SP: Manipulation and injection for hallux rigidus. Is it worthwhile?. Bone Joint J. 2001, 83(5):706-708. 10.1302/0301-620X.83B5.11425

20. Karasick D, Wapner KL: Hallux rigidus deformity: radiologic assessment . Am J Roentgenol. 1991, 157:1029-1033. 10.2214/ajr.157.5.1927789

21. Munteanu SE, Zammit G V, Menz HB, et al.: Effectiveness of intra-articular hyaluronan (Synvisc, hylan G-F 20) for the treatment of first metatarsophalangeal joint osteoarthritis: a randomized placebo-controlled trial. Ann Rheum Dis. 2011, 70:1838-1841. 10.1136/ard.2011.153049

22. Pons M, Alvarez F, Solana J, Viladot R, Varela: Sodium hyaluronate in the treatment of hallux rigidus. A single-blind, randomized study. Foot ankle Int. 2007, 28(1):38-42. 10.3113/FAI.2007.0007

23. Grice J, Marsland D, Smith G, Calder J: Efficacy of foot and ankle corticosteroid injections . Foot Ankle Int. 2017, 38(1):6-11. 10.1177/1071100716670160

24. Maher A, Price M: An audit of the use of sodium hyaluronate $1 \%$ (ostenil mini) therapy for the conservative treatment of hallux rigidus. Br J Pod. 2007, 10(2):47-51.

25. Petrella RJ, Cogliano A: Intra-articular hyaluronic acid treatment for Golfer's toe. Phys Sportsmed. 2004, 32(7):41-45. 10.3810/psm.2004.07.453

26. Steinberg MD: Therapy of osteoarthritis of the great toe and hallux rigidus . JAMA. 1971, 


\section{Cureus}

217(2):215. 10.1001/jama.1971.03190020073030

27. Brantingham JW, Globe G, Pollard H, Hicks M, Korporaal C, Hoskins W: Manipulative therapy for lower extremity conditions: expansion of literature review. J Manipulative Physiol Ther. 2009, 32(1):53-71. 10.1016/j.jmpt.2008.09.013 